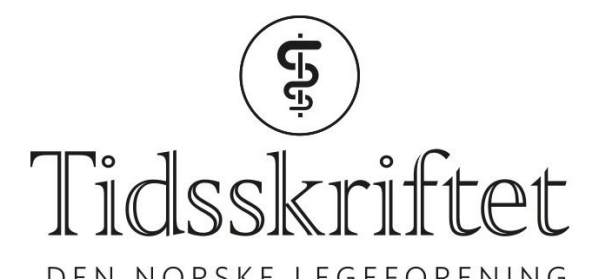

\title{
Hvem lærte dig paa egne ben at staa?
}

TIDLIGERE I TIDSSKRIFTET

JULIE DIDRIKSEN

Tidsskriftet

På legemøtet i Trondheim i 1920 slo en overlege til med det som i dag mest av alt fremstår som en pinlig tale til de kvinnelige legene rundt bordet. Talen sto på trykk i sin helhet $\mathrm{i}$ Tidsskriftets utgave 22/1920 (Tidsskr Nor Lægeforen 1920; 40: 782-3).

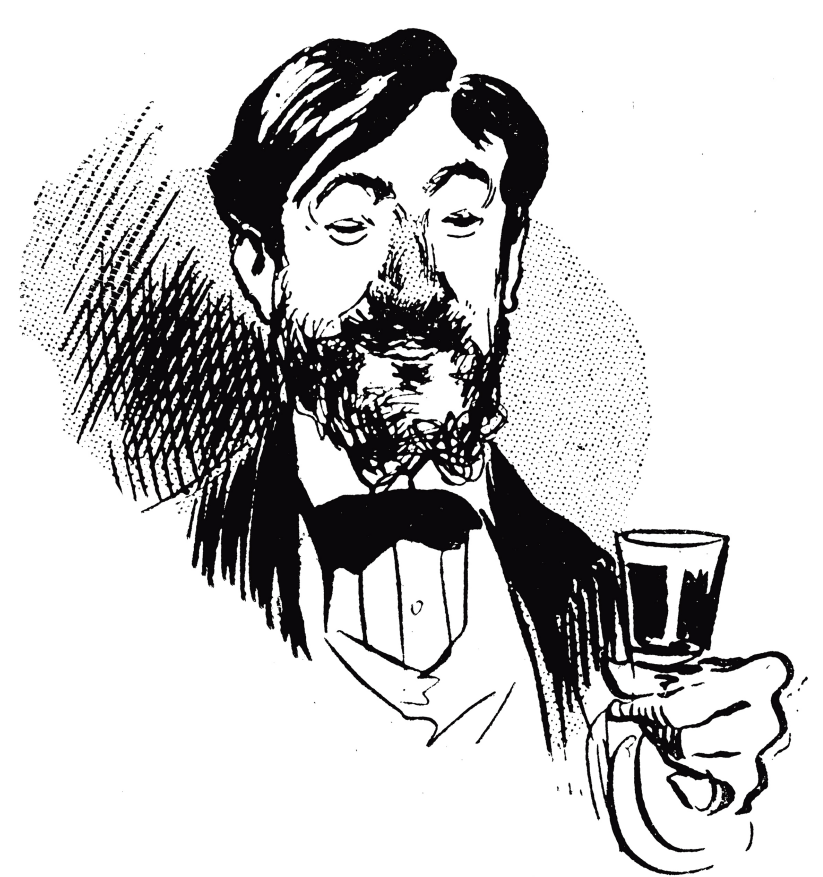

Illustrasjon: ilbusca/iStock

Nu! Talen for disse yndige søte

damer er holdt paa hvert lægemøte,

saa vi kunde den resolutionen ta

at 18de møte er enig i, hvad 17de sa.

Jeg finder det dog i den anledning

paakrævet at gi en kort utredning 
av forskjellige spørsmaal, som reises kan

om relationen mellem kvinde og mand.

For - hvis det er mulig - at faa saken klar

skal jeg stille en række spørsmål og svar.

Min herre:

Hvem var det, dig velkommen bad

til denne jammerdal, da du sat

og rød og hvit i vuggen laa

og dit sind var rent og øinene blaa?

- En kvinde.

Hvem lærte dig paa egne ben at staa

og siden paa egne ben at gaa?

Hvem var det du slaas med, da du var liten,

og hvem har du stadig kjæmpet med siden?

- En kvinde.

Hvem var det, som først fik dit hjerte at brænde?

Hvem var det, som først fik dit hjerte at brænde?

For hvem blev du digter? - Hvem andre end - hende.

Hvem var det, som først et kys dig ga

og hvem var den første du stjal et fra?

Hvem bestemmer hvem en doktors karriere,

nar han skal hentes og naar man skal la være?

Hvis sikre træk er det man eier,

naar man ser paa lillemors hals eller lilleguts - bleier?

Hvem er det, som setter os graa haar i hodet,

men trøster vor sjæl, naar vi selv taper modet?

Hvem er det, som bruker op vore penger

og sparer for os, naar vi ikke har nogen længer?

Hvem varmer en op, naar træt og vaat

man vender hjem fra reise i bil eller baat?

Hvem sætter da kjærlig tøflerne frem

og samtidig holder os stramt under dem?

Hvem er det, hvis bløte armer og kind

saa ofte har læget vort syke sind?

Hvem gjør os bløte som voks og haarde som staal,

som gir os et hjem, og livet et maal?

Vi ønsker ikke at se helt tilbunds i de fængslende blikke

Hvem er det, som sier, skjønt vi blir graa 
at vi holder os unge, - men skaffer os smaa

søte «spirer», med hvis respekt det er tyndt,

de kalder os «gammeln» og slaar os for munt.

Mine herrer! Spørsmaalene kan forfleres.

Jeg tror dog ikke, de kan diskuteres,

og jeg bør vist ikke, skjønt jeg har ordet,

gaa i detalj om kvinderne her ved bordet.

Skulde de ønske en utredning siden,

skal jeg staa til tjeneste ogsaa «utenfor tiden».

Det var engang, jeg trodde som gynækolog

at kunne læse kvinnen som en opslaat bok;

men, mine herrer: Skal vi sandhet si,

saa er det det vi ønsker, at kvinden skal bli,

den evige gaate. Vi ønsker ikke

at se helt tilbunds i de fængslende blikke.

La hun bli den hun er, fjern eller nær!

Kvindens skaal! En skaal for hende, som er os kjær.

Publisert: 29. juni 2020. Tidsskr Nor Legeforen. DOI: 10.4045/tidsskr.20.0086

C Tidsskrift for Den norske legeforening 2020. Lastet ned fra tidsskriftet.no 